\title{
KUALITAS HIDUP MANTAN PECANDU NARKOBA YANG SEDANG MENJALANI TERAPI METADON
}

\author{
Gede Indra Surya Lasmawan dan Tience Debora Valentina \\ Program Studi Psikologi, Fakultas Kedokteran, Universitas Udayana \\ indraasuryaa22@gmail.com
}

\begin{abstract}
Abstrak
Penyalahgunaan narkoba di berbagai belahan dunia semakin luas. Begitu pula di Indonesia, tahun 2013 hasil survey Badan Narkotika Nasional menunjukkan terdapat sekitar 3,8 juta penduduk Indonesia sebagai pengguna narkoba. Berbagai kasus menunjukkan kerugian materi maupun non materi dan bahkan menyebabkan kematian. Oleh sebab itu, seorang pecandu narkoba sebaiknya segera berhenti dan wajib menjalani proses pemulihan. Metode terapi dengan pendekatan medis yang efektif dan diakui hingga saat ini adalah program pengalihan narkoba ke zat lain yang disebut dengan terapi metadon (Puspita, 2008). Terdapat berbagai manfaat positif yang membuat pasien berfungsi secara normal, namun terapi metadon juga menimbulkan efek samping dan adanya ketergantungan yang dapat mempengaruhi secara psikologis kualitas hidup pasien (Maeyer, 2011). Hal inilah yang membuat peneliti tertarik untuk meneliti mengenai kualitas hidup mantan pecandu narkoba yang sedang menjalani terapi metadon mencakup aspek fisik, psikologis, sosial, dan lingkungan

Penelitian ini menggunakan metode kualitatif dengan desain fenomenologi, serta observasi dan wawancara sebagai teknik penggalian data yang dilaksanakan di Denpasar. Responden sebanyak empat orang yang menjalani terapi metadon. Hasil penelitian menunjukkan bahwa penggunaan metadon membantu individu dalam berbagai aspek kualitas hidup seperti aspek kesehatan fisik yaitu individu dapat kembali beraktivitas secara normal. Pada aspek psikologis, individu memiliki motivasi untuk mencapai harapannya dan tidak terpuruk dalam penyesalan. Terkait aspek hubungan sosial, orang terdekat memberikan dukungan dan motivasi. Selanjutnya aspek kesejahteraan lingkungan yaitu individu masih dapat menjalani pekerjaan untuk memenuhi kebutuhan.
\end{abstract}

Kata Kunci: kualitas hidup, mantan pecandu narkoba, terapi metadon

\begin{abstract}
Over time, drugs abuse in various parts of the world increase widely. Similarly in Indonesia, the results of a survey conducted by the National Narcotics Agency revealed that there are 3.8 million people in Indonesia are drugs user in 2013. Various cases showed that the impact of drugs abuse seen in the loss of materials and non-materials, and can even cause death. Therefore, people who addicted to drugs should immediately stop consuming and required to undergo a recovery process. Therapeutic method with medical approaches recognized until now are diversion programs to substitute drugs or other substance called methadone therapy (Puspita, 2008). Although there are many positive benefits that make the patient to function normally, but methadone therapy also cause side effects and dependence that can psychologically affect the quality of life of patients (Maeyer, 2011). This makes the researcher interested in studying the quality of life of former drugs addicts undergo methadone treatment.

This study used a qualitative method with a phenomenological design with interview and observation as data collection techniques. Respondents were four patients who involve in methadone therapy. Results of the study shows that methadone helps individuals in various aspects of quality of life such as physical health aspect, where the individual can return to normal activities. In the psychological aspects, the individual has motivation to reach higher accomplishment and not mired in regret. Relate to aspects of social relations, family members give support and motivation. Furthermore, environmental aspect showed that individuals have their own work to fulfill their necessary.
\end{abstract}

Keywords: quality of life, former drugs addicts, methadone therapy 


\section{LATAR BELAKANG}

Narkoba (narkotika, psikotropika, dan obat berbahaya) pada dasarnya sejak lama telah digunakan oleh umat manusia. Banyak jenis narkotika dan psikotropika memberi manfaat besar bila digunakan dengan baik dan benar. Dalam bidang kedokteran narkotika dan psikotropika dapat menyembuhkan berbagai penyakit dan mengakhiri penderitaan. Manfaat lain dari narkoba yakni seperti yang terjadi di Aceh dan daerah Sumatera lainnya, banyak tumbuh ganja yang telah lama digunakan oleh masyarakat setempat sebagai bahan ramuan makanan sehari-hari (Setyawan, 2012). Hal ini menandakan, narkoba tidak selalu memberikan dampak buruk. Timbulnya permasalahan yaitu ketika narkoba disalahgunakan dan digunakan secara berlebihan. Dampak bagi penyalahgunaan narkoba yaitu dapat menyebabkan seseorang menjadi ketagihan terhadap narkoba secara terus menerus, sedangkan ketika digunakan secara berlebihan dapat menyebabkan overdosis dan kematian (Wasis \& Irianto, 2008).

Seiring berjalannya waktu, penyalahgunaan narkoba di berbagai belahan dunia semakin luas, bagitu pula Indonesia. Penanganan penyalahgunaan narkoba di berbagai daerah ibarat fenomena gunung es, yang terlihat hanya yang muncul saja, namun sesungguhnya keadaan yang berada di bawah permukaan jauh lebih banyak dan lebih besar (Iswanti, dkk., 2007). Berdasarkan hasil survey yang dilakukan oleh Badan Narkotika Nasional (BNN) pada tahun 2013, terdapat sekitar 2,2\% atau sekitar 3,8 juta penduduk Indonesia sebagai pengguna narkoba. Peredaran dan permasalahan narkoba di Indonesia menunjukkan kecenderungan untuk terus meningkat, hal ini dapat dilihat dari bertambahnya pecandu dan jumlah narkoba yang disita. Hal ini dikarenakan Indonesia yang pada awalnya merupakan negara transit atau pemasaran, kini telah menjadi negara tujuan, dan bahkan sebagai negara produsen yang dapat mengekspor narkoba(Manurung, 2009).

Salah satu jenis penyalahgunaan narkoba yang terbesar adalah jenis heroin atau putaw. Berdasarkan data yang diperoleh dari BNN, pada tahun 2011 terdapat 37.989,81 gram narkoba jenis ini dan terus meningkat sebesar $72,4 \%$ menjadi 52.425,54 pada tahun 2012 (BNN, 2013). Data tersebut didukung dengan data yang diperoleh dari Pencegahan dan Pemberantasan Penyalahgunaan dan Peredaran Gelap Narkotika (P4GN) pada tahun 2012, tercatat sekitar 17.734 orang mendapatkan pengobatan ataupun rehabilitasi di seluruh Indonesia, dan jenis narkoba yang paling banyak digunakan yaitu heroin yang berjumlah 10.768 orang, ganja sebanyak 1.774 orang, sabu-sabu berjumlah 984 orang, dan sisanya pengguna jenis lain (Simarmarta, 2013). Heroin pada umumnya digunakan dengan menyuntikkannya ke dalam intravena, atau yang sering disebut dengan pengguna narkoba suntik (penasun), dan dalam istilah asing disebut Injecting
Drug User (IDU). Hal ini dapat menyebabkan peningkatan pada penderita penyakit menular seksual, seperti HIV dan AIDS, sifilis, hepatitis $\mathrm{B}$, hepatitis $\mathrm{C}$, dan lain sebagainya (Partodihardjo, 2010).

Masalah penyalahgunaan narkoba di Indonesia merupakan masalah serius yang segera harus ditemukan penyelesaiannya. Berbagai kasus yang menunjukkan dampak dari permasalahan narkoba menyebabkan kerugian baik materi maupun non materi, seperti kecelakaan, permasalahan keluarga, tertular penyakit, atau kesulitan lain, bahkan kematian yang disebabkan oleh ketergantungan narkoba. Oleh sebab itu, seorang pecandu narkoba sebaiknya segera berhenti menggunakan narkoba dan wajib menjalani proses pemulihan sesuai dengan kebutuhan masing-masing. Hal ini sesuai dengan UU Nomor 35 tahun 2009 tentang narkotika pada pasal 54 menyebutkan, "Pecandu Narkotika dan korban penyalahgunaan Narkotika wajib menjalani rehabilitasi medis dan rehabilitasi sosial". Di Indonesia kini telah tersedia tempat khusus guna menangani kasus penyalahgunaan narkoba, dan juga berbagai jenis program terapi dan rehabilitasi untuk mengurangi dampak negatif dari penggunaan narkoba. Pelaksanaannya dilakukan dalam berbagai setting, seperti panti rehabilitasi milik swasta ataupun pemerintah, dan setting kesehatan seperti puskesmas atau rumah sakit, yang dikembangkan berupa program rehabilitasi dan detoksifikasi (Agung, 2010).

Berdasarkan data yang diperoleh, jenis penyalahgunaan narkoba yang terbesar adalah jenis heroin, dan hingga saat ini metode terapi dengan pendekatan medis yang paling efektif dan diakui dalam menangani ketergantungan heroin yaitu program pengalihan (substitusi) narkoba yang mengalihkan pada zat lain atau yang disebut dengan terapi metadon (Puspita, 2008). Menurut UU Nomor 22 tahun 1997 tentang Narkotika, terapi metadon adalah sebuah metode terapi khusus untuk ketergantungan opiat jenis heroin berupa pengalihan dari penyalahgunaan heroin yang termasuk golongan I (dilarang pemakaian untuk terapi) menjadi menggunakan metadon yang termasuk golongan II (biasa digunakan untuk terapi). Terapi substitusi ini merupakan salah satu upaya pengurangan dampak buruk (harm reduction) yang disebabkan oleh penyalahgunaan narkoba, terutama penyalahgunaan narkoba dengan menggunakan jarum suntik atau disebut dengan Injecting Drug User (IDU), agar terhindar dari penyakit menular serta mengobati ketergantungan para pecandu narkoba yang kini dikenal sebagai Program Terapi Rumatan Metadon (PTRM). PTRM merupakan program jangka panjang dengan dosis yang berbeda-beda setiap individu, berdasarkan tingkat keparahan penggunaan heroin. Metadon tidak disuntik melainkan diminum, dosisnya naik secara perlahan, dan apabila telah stabil, maka dapat turun secara perlahan serta diminum setiap hari (Okvianus, 2010). 
Di Indonesia sendiri, PTRM atau terapi metadon pertama kali diterapkan di Rumah Sakit Ketergantungan Obat (RSKO) Jakarta, dan RS Sanglah Bali, dan diperoleh hasil yang positif yakni terjadinya perbaikan kualitas hidup baik fisik maupun psikologis, penurunan angka kriminalitas, perbaikan hubungan sosial, penurunan depresi, dan lain sebagainya (Depkes, 2007). Preston (2006) menjelaskan terkait berbagai manfaat dari terapi metadon diantaranya dapat membantu pengguna metadon beraktivitas mendekati kehidupan normal, dan dapat berhenti atau mengurangi penggunaan heroin. Berdasarkan penuturan salah satu seorang mantan pecandu narkoba yang sedang menjalani terapi metadon, terkait hal yang dirasakan serta harapan selama menjalani terapi, terungkap bahwa menggunakan metadon membuat individu menjadi normal dan tidak sakit. Metadon dirasa tepat karena membuat individu terhindar dari penyalahgunaan heroin, namun menggunakan metadon dirasa individu sulit untuk menurunkan dosis. Individu berharap agar dapat segera sembuh dari penggunaan metadon, agar menjadi orang yang normal dan dapat bekerja kembali (Lasmawan, 2013).

Terdapat berbagai manfaat positif dari metadon, namun metadon juga dapat memberi efek samping terhadap individu pengguna metadon, seperti penurunan rangsangan seksual, rasa berat pada tangan dan kaki, lesu, penurunan frekuensi menstruasi, serta memunculkan keinginan untuk memakan makanan yang manis (Preston, 2006). Dapat disimpulkan bahwa terapi metadon dapat membantu individu dalam menjalankan aktivitas sehari-hari, namun terdapat pula efek samping yang dirasakan oleh individu. Hal ini menunjukkan bahwa penggunaan metadon dapat memengaruhi kualitas hidup individu yang sedang menjalani terapi metadon.

Coons \& Kaplan (dalam Sarafino, 1994) menjelaskan bahwa kualitas hidup adalah suatu pandangan umum yang terdiri dari beberapa komponen dan dimensi dasar yang berhubungan dengan kesehatan, diantaranya fungsi fisik, keadaan psikologis, fungsi sosial dan penyakit serta perawatannya. Kualitas hidup mengarah pada kenikmatan maupun kepuasan dari kehidupan sehari-hari, yang berkaitan dengan kesehatan fisik dan mental (Ventegodt, 2003). Stewart dan Ware (1992) menyebutkan kesehatan fisik seseorang dapat dilihat dari keterbatasan peran, fungsi fisik, maupun adanya rasa nyeri, serta bagaimana persepsi individu terkait kesehatan, sedangkan kesehatan mental dilihat dari keterbatasan peran secara emosional serta keterbatasan fungsi sosial yang dialami. Kualitas hidup mantan pecandu narkoba yang menjalani terapi metadon menjadi masalah yang menarik perhatian bagi para profesional kesehatan. Metadon yang diyakini dapat memberi dampak positif pada individu pengguna metadon ternyata dapat menimbulkan berbagai efek samping yang berdampak pada kualitas hidup, sehingga tujuan penelitian ini adalah untuk melihat kualitas hidup mantan pecandu narkoba yang sedang menjalani terapi metadon.

Berdasarkan pemaparan diatas menarik bagi peneliti untuk meneliti mengenai kualitas hidup mantan pecandu narkoba yang sedang menjalani terapi metadon, melalui berbagai aspek kualitas hidup seperti kesehatan fisik, psikologis, hubungan sosial maupun lingkungan.

\section{METODE}

\section{Pendekatan}

Metode yang akan digunakan dalam penelitian ini adalah metode penelitian kualitatif dengan pendekatan fenomenologi. Metode kualitatif mengarahkan dan membantu peneliti untuk lebih dekat dengan gejala sebagaimana peneliti mengalami, menghayati, serta menghidupi gejala dengan sebenarnya (Abidin, 2002). Desain penelitian kualitatif yang digunakan untuk memahami kualitas hidup mantan pecandu narkoba yang sedang menjalani terapi metadon adalah fenomenologi. Fenomenologi merupakan sebuah studi yang memberikan gambaran mengenai arti dari pengalamanpengalaman beberapa individu mengenai suatu konsep tertentu. Fenomenologi berusaha untuk mengungkap dan mempelajari serta memahami suatu fenomena beserta konteks yang khas dan unik yang dialami oleh individu hingga tataran keyakinan individu yang bersangkutan (Herdiansyah, 2010).

\section{Responden}

Penelitian ini menggunakan teknik sampel bertujuan (purposive sample). Creswell (1998) menyebutkan bahwa dalam penelitian fenomenologi jumlah responden berkisar antara 3 - 10 responden. Dalam penelitian ini terdapat empat responden, dengan kriteria yaitu mantan pecandu narkoba yang sedang menjalani terapi metadon, tidak menggunakan narkoba selama kurang lebih satu tahun, menggunakan metadon selama kurang lebih dua tahun, tinggal dengan keluarga (orangtua / istri / suami), rentang usia 20 - 40 tahun, jenis kelamin tidak dibatasi, dan pendidikan minimal SMP.

\section{Tempat Penelitian}

Penelitian ini dilakukan di Denpasar dan dimulai sejak bulan Januari 2014. Penelitian ini diawali dengan tahap penyusunan proposal penelitian, penentuan kategori responden, pencarian responden yang sesuai dengan kategori yang telah ditentukan, pre eliminary study atau wawancara awal, penyusunan panduan wawancara, dan proses pengambilan data dengan metode wawancara dan observasi. 


\section{Teknik Pengumpulan Data}

Teknik pengumpulan data yang digunakan dalam penelitian ini yaitu teknik wawancara semi terstruktur dan teknik observasi non-partisipan yang dilakukan ketika dilakukannya wawancara terhadap responden baik pada wawancara pre eliminary study, wawancara secara mendalam dengan responden, dan juga ketika wawancara dengan significant other dari responden penelitian dengan metode pencatatan yang digunakan adalah secara naratif.

\section{Teknik Analisis Data}

Metode analisis data yang digunakan dalam penelitian ini adalah metode kualitatif dengan teknik modifikasi dari metode Stevick-Colaizzi-Keen (Moustakas dalam Creswell, 1998). Langkah-langkah yang diaplikasikan ke dalam penelitian yaitu diawali dengan menyusun deskripsi lengkap dari pengalaman terhadap fenomena selama menggunakan terapi metadon. Dilanjutkan dengan memilih pernyataan yang berkaitan dengan aspek kualitas hidup, melakukan penyusunan, dan mendata pernyataan yang signifikan. Setelah itu, membangun dan mengembangkan daftar pernyataan yang tidak berulang agar tidak tumpang tindih. Pernyataan kemudian dikelompokkan menjadi kesatuan makna, yang disusun dengan deskripsi tekstural, termasuk contoh verbatim. Peneliti kemudian membangun suatu dinamika dari pengalaman ketika menggunakan narkoba hingga menggunakan metadon menggunakan variasi imajinatif dari peneliti. Diakhiri dengan mengaitkan temuan dengan berbagai konsep yang berkaitan.

Trianggulasi dalam penelitian ini dilakukan dengan beberapa cara diantaranya, trianggulasi sumber data dilakukan dengan melakukan wawancara terhadap orang terdekat responden, trianggulasi metode dilakukan dengan menggunakan laporan diri, wawancara, dan observasi dalam penggalian data, lalu trianggulasi teori dilakukan dengan menggunakan acuan teori beberapa tokoh. Langkah selanjutnya yaitu analisis negative yang dilakukan dengan membandingkan dua kelompok responden antara yang bekerja di LSM dan tidak, kemudian mengaitkan temuan dengan referensi yang berkaitan, serta pengecekan kembali data yang diperoleh.

\section{Isu Etis}

Dalam rangka menjaga penelitian ini berlangsung dengan baik dan tidak membebani serta merugikan para responden dalam penelitian, maka dilakukanlah langkahlangkah sebagai berikut, mendapatkan persetujuan dari responden penelitian berupa inform consent tertulis maupun dalam bentuk rekaman, tidak adanya unsur dalam penelitian ini yang merugikan atau membahayakan responden, menjaga kerahasiaan responden, menyimpan rekaman, responden berhak mundur di tengah penelitian, dan memberikan hasil penelitian kepada institusi dan responden (jika diminta).

\section{HASIL PENELITIAN}

\section{Pengertian Kualitas Hidup Menurut Responden}

Responden satu mendefinisikan kualitas hidup sebagai kondisi kehidupan yang mapan dan terbebas dari narkoba. Kualitas hidup yang dirasakan responden sejauh ini yaitu responden merasa diri dalam keadaan bimbang, dengan kondisi fisik yang tidak nyaman, serta sugesti yang begitu sering muncul. Pada responden dua kualitas hidup diartikan sebagai keadaan hidup atau gambaran hidup yang lebih layak dari kehidupan sebelumnya, yang berkaitan dengan makan serta tidur yang teratur dan juga bekerja lebih baik lagi. Berdasarkan hal tersebut responden mempersepsikan hidupnya sejauh ini sudah terpenuhi dalam hal kebutuhan sehari-hari, namun sejauh ini mengenai pola makan dan istirahat belum sepenuhnya teratur.

Responden tiga mendefinisikan kualitas hidup sebagai kondisi atau gambaran kehidupan yang berkaitan dengan kehidupan yang nyaman, pekerjaan dan ekonomi terpenuhi, tidak mengalami stres, hidup berkecukupan, serta dapat menerima kondisi yang terjadi. Berdasarkan pemahaman yang dipaparkan, responden menyadari bahwa pencapaian hidupnya saat ini sebesar $60 \%$, hal ini disebabkan karena terdapat beberapa faktor yang belum terpenuhi seperti hubungan ke masyarakat, meskipun kepercayaan terhadap dirinya telah kembali, namun terkait kebutuhan sejauh ini dirasa sudah mencukupi.

Pada responden empat kualitas hidup diartikan sebagai gambaran keseimbangan hidup yang berkaitan dengan kesehatan, makanan, kebersihan, dan juga pemenuhan materi. Pemenuhan kualitas hidup dapat dicapai dengan melakukan olahraga yang teratur, tidur dengan teratur, makan yang teratur, serta uang yang mencukupi. Responden mepersepsikan pemenuhan kualitas hidupnya saat ini masih terkendala dalam hal ekonomi, responden menyadari bahwa kehidupan sebelumnya membuat responden sering mengalami perselisihan dengan istri dan anak menjadi korban, sehingga dengan menyadari hal tersebut responden bertekad untuk mengatur kembali kehidupannya guna meningkatkan kualitas hidupnya.

\section{Dampak Penggunaan Metadon}

Berbagai dampak dirasakan oleh masing-masing responden akibat penggunaan metadon. Tidak hanya berdampak fisik, namun juga berdampak pada psikologis penggunanya. Penggunaan metadon yang dijalani masing- 


\section{KUALITAS HIDUP MANTAN PECANDU NARKOBA}

masing responden memberikan efek sakaw terhadap responden. Hal ini terjadi apabila responden terlambat meminum metadon, sakaw yang dirasakan responden berupa perasaan gelisah, tubuh menjadi berkeringat, tidak enak makan atau minum, tubuh terasa nyeri, dan sulit mengendalikan emosi. Hal ini pernah dialami oleh keempat responden selama menggunakan metadon.

Nafsu makan yang meningkat dialami oleh salah satu responden penelitian, yaitu terjadi pada responden 1 . Hal ini disadari oleh ibu responden yang melihat anaknya rutin mengkonsumsi makanan, dan hal ini menyebabkan berat badan responden semakin meningkat. Penggunaan metadon dalam dosis yang tinggi dapat menyebabkan responden menjadi susah buang air besar. Hal ini pernah dialami oleh keempat responden, responden satu, tiga, dan empat kini telah jarang mengalami susah buang air besar karena secara perlahan mulai menurunkan dosis. Tidak demikian pada responden dua, responden dua penggunaan dosis metadon terbilang tinggi yaitu pada dosis 100mg, dan membuat responden dua mengalami kesulitan untuk buang air besar, sehingga hampir setiap hari responden menghabiskan waktu berjam-jam berdiam di kamar mandi.

Responden juga merasakan penurunan gairah seksual, sehingga intensitas dalam melakukan hubungan seksual menjadi berkurang dibandingkan sebelum menggunakan metadon. Hal ini dirasakan oleh tiga dari empat responden penelitian, dikarenakan satu responden belum menikah sehingga hubungan seksual tidak dapat tergambarkan. Penggunaan metadon juga membuat keempat responden merasakan keropos pada bagian gigi. Hal ini membuat salah satu responden sering pergi ke dokter gigi, untuk memeriksakan giginya.

Perubahan penampilan terjadi setelah responden menggunakan metadon, keempat responden merasa dirinya lebih memperhatikan penampilan dibandingkan ketika masih mengunakan narkoba. Dampak secara psikologis yang dirasakan responden ketika menggunakan metadon, yaitu rasa nyaman. Hal ini dirasakan oleh responden dua yang merasa nyaman dengan dosis metadon saat ini, namun apabila dosis diturunkan responden kembali merasa tidak nyaman. Dampak lain yang juga dirasakan ketika menggunakan metadon yaitu membuat kemampuan berpikir dan kepercayaan diri responden menurun. Hal ini dirasakan oleh responden empat yang merasa dirinya tidak seperti dulu lagi.

Semenjak menggunakan metadon hubungan masingmasing responden dengan orang-orang disekitarnya semakin membaik, seperti hubungan dengan orangtua, hubungan dengan istri, keluarga, maupun dengan masyarakat, belum semua anggota masyarakat dan keluarga sepenuhnya mempercayai responden. Tiga dari empat responden merasakan penurunan gairah seksual, namun yang paling merasakan dampak dari metadon adalah responden tiga.
Responden tiga ingin segera memiliki anak, sehingga hal ini menyulitkan responden untuk memenuhi keinginannya, dan membuat istri responden sedikit kecewa.

Masing-masing responden juga merasakan dampak yang cenderung positif dari metadon, yaitu kini responden dapat terhindar dari penggunaan heroin yang lebih membahayakan dan harga metadon yang relatif murah dirasa tidak menyulitkan responden. Di sisi lain menggunakan metadon membuat responden merasa tidak bebas untuk bepergian, hal ini dirasakan oleh responden satu, yang sulit meminta metadon dalam jumlah lebih yang akan dibawa keluar kota.

\section{Kualitas Hidup Pengguna Metadon}

\section{a. Kualitas Hidup Responden 1}

Kualitas hidup responden satu terkait kondisi fisik, ditemukan bahwa responden dapat menjalani aktivitas dengan normal, tanpa merasakan sakit. Apabila tidak menggunakan metadon responden merasakan sakaw seperti timbulnya rasa nyeri, sulit mengendalikan emosi. Nafsu makan responden kini semakin meningkat, hal ini menyebabkan berat badan responden meningkat. Responden ingin menurunkan berat badannya, namun mengalami kesulitan akibat penyakit hepatitis $\mathrm{C}$ yang dideritanya, dan tidak memungkinkan subek untuk olahraga terlalu berat. Terkait kapasitas kerja, responden tidak mampu mengambil pekerjaan lain selain pekerjaan utama sebagai staf di sebuah LSM. Responden sempat mencoba untuk bekerja di malam hari, namun responden merasa ngantuk dan malas. Keluhan lain yang responden rasakan yakni mengenai gigi keropos yang juga responden alami saat ini.

Kualitas hidup responden satu terkait kondisi psikologis mengungkapkan bahwa sugesti untuk menggunakan narkoba muncul ketika menghadapi masalah keluarga, mendapat tawaran teman, ataupun melihat langsung narkoba. Responden merasa jenuh menjalani terapi, selain itu responden merasa sulit untuk menurunkan dosis metadon. Selain merasa cemas dengan ketergantungannya terhadap metadon, responden juga cemas dengan kontrak pekerjaan yang sebentar lagi akan habis. Responden juga merasa cemas dengan pengalaman ketika bekerja yaitu tanpa sengaja menginjak jarum lepasan. Responden takut dirinya tertular penyakit, dan responden telah melakukan tes, namun belum mengetahui hasilnya, karena belum melakukan tes terakhir. Terkait penampilan, responden kini menjadi lebih sehat dan lebih bersih, berbeda ketika masih menggunakan narkoba.

Kualitas hidup terkait hubungan sosial pada responden satu mengungkapkan bahwa hubungan dengan orang sekitarnya semakin membaik seperti ibu, teman, dan masyarakat. Responden menerima dukungan dari ibunya berupa bantuan yang diberikan ibunya terkait pekerjaan 
responden, dari keluarga responden lebih diperhatikan seperti responden dibarikan sepasang sepatu oleh pamannya, dan juga responden memiliki teman yang memudahkannya dalam bekerja. Hubungan responden dengan masyarakat sekitar kian membaik, meskipun masih ada yang belum percaya terhadap responden sepenuhnya.

Mengenai kualitas hidup responden terkait lingkungan, responden mengungkapkan bahwa terapi metadon pilihan yang tepat agar terhindar dari heroin. Dari segi uang yang dikeluarkan juga relatif murah. Hanya saja menggunakan metadon dirasa sulit apabila ingin menurunkan dosis, dan membuat responden tidak bebas untuk keluar kota. Terkait pekerjaan responden merasa kesulitan dalam melakukan penjangkauan, dan belum mampu untuk mendapatkan hasil lebih dari pekerjaan lain. Bekerja di sebuah yayasan membantu responden dalam mendapatkan informasi dan juga dalam mengembangkan kemampuannya melalui pelatihanpelatihan yang didapatkannya. Mengenai lingkungan rumah responden merasakan sedikit ketidaknyaman, responden kerap kali mencium bau kotoran babi yang terkadang membuat responden merasa tidak nyaman.

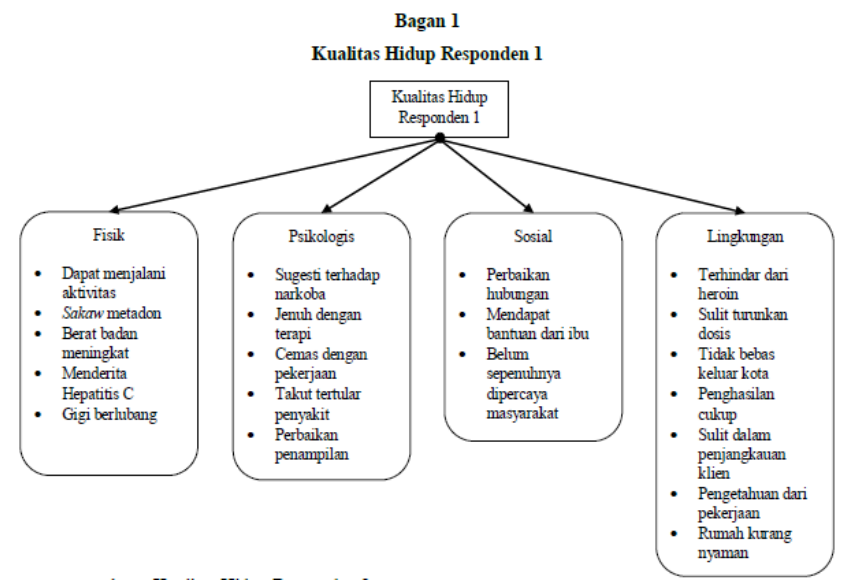

\section{b. Kualitas Hidup Responden 2}

Kualitas hidup responden dua terkait kondisi fisik diungkapkan bahwa responden dapat kembali bekerja. Metadon juga menimbulkan efek sakaw, seperti tubuh terasa nyeri, mudah marah, dan merasa tidak memiliki tenaga yang terjadi apabila tidak meminum metadon. Semenjak menggunakan metadon responden juga merasakan peningkatan berat badan, namun tidak begitu drastis yang disebabkan oleh kedekatan responden dengan anak. Responden juga merasa mudah lelah ketika menjalani aktivitas seperti bekerja, namun kesulitan untuk berisitirahat karena ada anak yang terkadang menggangu. Hal lain yang cukup menggangu bagi responden yaitu sulit untuk buang air besar, bahkan dapat menghabiskan waktu berjam-jam untuk melakukannya. Responden juga merasa gairah seksualnya menurun, dan gigi responden menjadi keropos.
Kualitas hidup responden dua terkait kondisi psikologis mengungkapkan bahwa responden saat ini mudah goyah, apabila menerima tawaran dan tidak ditemani istri saat mengambil metadon. Responden mengaku mudah marah ketika mencoba menurunkan dosis penggunaan metadon, meskipun tanpa ada hal yang menjadi penyebab kemarahannya. Hal lain yang cukup membuat responden cemas yaitu ketika harus melakukan sosialisasi di banjar, timbul perasaan serta pikiran negatif yang membuat responden takut untuk bersosialisasi. Berdasarkan hasil penelitian, responden mengalami beberapa masalah, namun semenjak menggunakan metadon responden menjadi individu yang lebih memperhatikan dirinya. Selain itu responden merasa tidak terlalu memikirkan biaya untuk menjalani terapi ini.

Kualitas hidup mengenai hubungan sosial responden dua, mengungkapkan bahwa hubungan responden dengan keluarga yaitu orangtua, istri, ataupun anak menjadi lebih baik semenjak menggunakan metadon. Dukungan yang diterima responden dari istri yaitu istri yang selalu menemani responden untuk mengambil metadon, dan orangtua yang selalu memberikan nasihat kepada responden. Masalah yang vital bagi responden adalah hubungannya dengan masyarakat dimana responden semestinya melakukan kegiatan adat seperti ngayah (gotong royong umat Hindu di Bali), responden lebih memilih membayar denda dibandingkan harus terlibat langsung dalam aktivitas ngayah.

Mengenai kualitas hidup terkait lingkungan, responden mengungkapkan bahwa sumber penghasilan diperoleh dengan berjualan bersama dengan istri. Penghasilan yang didapat dirasa sudah cukup untuk memenuhi kebutuhan keluarga. Responden belum diijinkan oleh istri untuk bekerja diluar, sehingga penghasilan hanya di peroleh dengan berjualan. Responden mengungkapkan bahwa kondisi rumahnya yang kurang nyaman, responden juga mengaku jarang dalam melakukan rekreasi, namun terkait transportasi terasa lebih mudah karena sudah mampu membeli motor semenjak berjualan.

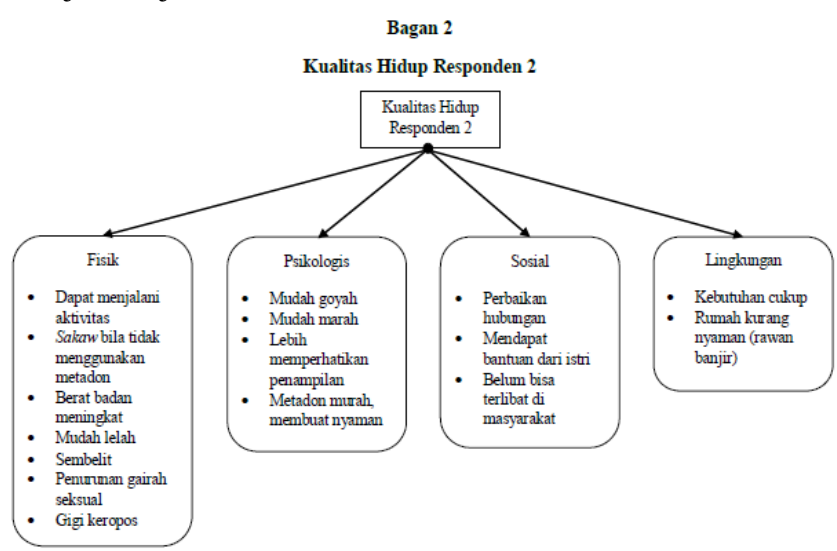

c. Kualitas Hidup Pengguna Metadon Responden 3 
Kualitas hidup terkait kondisi fisik responden tiga mengungkapkan bahwa menggunakan metadon membantu responden untuk dapat bekerja kembali. Responden dapat menjalani aktivitas yang padat dari pagi hingga malam hari. Mengenai kapasitas kerja, responden mengaku mampu melebihi kapasitas orang lain dimana responden bekerja. Responden tidak akan menyerah sebelum menyelesaikan pekerjaannya, namun responden juga tidak mamaksakan dirinya, karena menyadari bahwa dirinya tidak akan bekerja dengan baik apabila berada dalam kondisi kelelahan. Beberapa keluhan fisik sempat responden rasakan, diantaranya sakit bagian pinggang yang responden yakini karena menderita hepatitis $\mathrm{C}$, sesak yang disebabkan oleh rokok dan kopi, dan juga keram di pagi hari. Gigi responden juga perlahan mulai rapuh, sehingga responden beberapa kali sempat ke dokter gigi. Masalah yang cukup vital bagi responden adalah turunnya gairah seksual, karena responden berkeinginan untuk segera memiliki anak.

Kualitas hidup terkait kondisi psikologis responden tiga mengungkapkan bahwa menggunakan metadon membantu responden menjadi pribadi yang baru responden lebih memperhatikan penampilannya, perasaan sesuai dengan situasi yang terjadi disekitarnya, dan lebih baik dalam mengontrol emosinya. Mengenai sugesti, responden akui masih ada, namun responden dapat mengendalikannya. Responden terkadang merasa stres apabila belum mampu menyelesaikan pekerjaannya, responden akan berusaha keras untuk menemukan solusi dari masalah yang dialami. Kepercayaan diri responden kini semakin meningkat, responden sudah dapat menerima diri dan tidak begitu mempedulikan pendapat orang lain terhadap dirinya.

Mengenai kualitas hidup terkait hubungan sosial, responden mengungkapkan bahwa telah terjadi perubahan, hubungan dengan keluarga membaik dengan mulai dilibatkan pada rapat keluarga, dan hubungan dengan istri juga membaik meskipun responden merasa waktu yang diberikan kepada istri dirasa masih kurang. Dukungan penuh diterima responden dari istri maupun orangtua, istri selalu mengingatkan responden untuk mengambil metadon, dan orangtua yang selalu menanyakan kabar. Begitu pula di masyarakat, responden sudah mulai diterima, dan dukungan yang diterima berupa pemberian ijin dari masyarakat, ketika responden akan meminum metadon. Responden menyadari waktu yang diberikan untuk keluarga dan masyarakat masih kurang, namun apabila responden telah mapan maka saat itu responden akan menebus perhatian yang kurang. Penurunan gairah seksual cukup menjadi perhatian bagi responden, karena keinginan responden untuk segera memiliki anak, hal ini juga membuat istri responden sedikit kecewa, namun istri responden dapat memahami hal tersebut.

Kualitas hidup terkait lingkungan responden tiga mengungkapkan sumber penghasilan diperoleh dari beberapa pekerjaan. Selain bekerja di LSM responden juga menyediakan jasa servis laptop, pembuatan baju, dan lain sebagainya. Pekerjaan yang dijalani tidak begitu berat, sehingga hasilnya tidak seberapa. Penghasilan saat ini dirasa masih kurang, selain responden kurang mampu mengatur keuangan, kebutuhan hidup yang semakin meningkat juga menjadi faktor lain yang memengaruhi. Responden merasa penghasilannya masih kurang, namun bekerja di LSM membantu responden mendapatkan informasi, dan ilmu-ilmu yang selama ini belum responden dapatkan. Terkait dengan lingkungan metadon, responden merasa cukup membantu pekerjaannya, karena responden mendapatkan informasi tentang perkembangan teman, meskipun masih ada yang menggunakan narkoba, responden tidak mempedulikannya. Terkait perawatan (terapi metadon) yang responden jalani dirasa masih bagus, namun kurang maksimal. Responden merasa konseling, pertemuan dengan tim medis, serta kunjungan rumah perlu ditingkatkan.

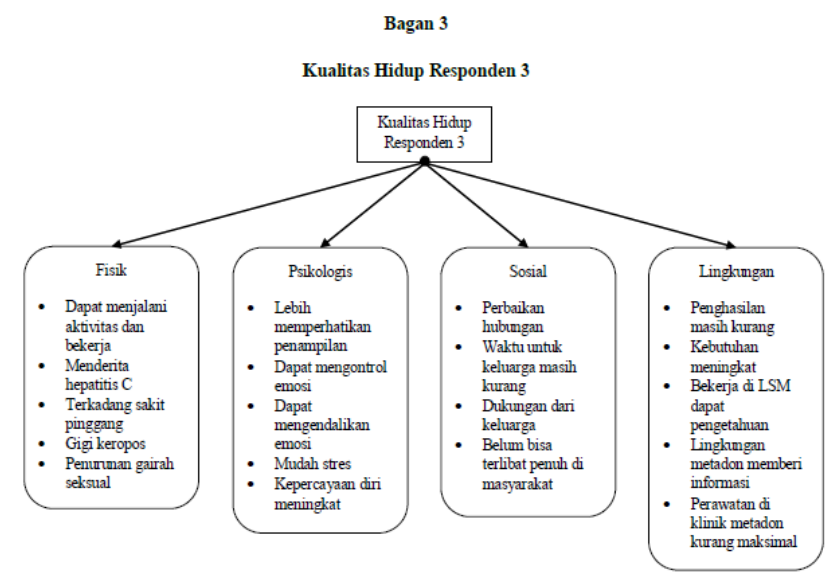

\section{d. Kualitas Hidup Pengguna Metadon Responden 4}

Kualitas hidup terkait kondisi fisik pada responden empat mengungkapkan bahwa kini responden lebih terkontrol, dan apabila ada pekerjaan dapat dijalani oleh responden. Beberapa keluhan fisik serta penyakit responden derita, responden sering mengeluhkan giginya yang mulai keropos. Responden saat ini juga menderita hepatitis $C$, dan pengobatannya cukup mahal. Selain menderita hepatitis $C$ responden juga menderita diabetes, apabila gula darah responden meningkatkan membuat responden menjadi lemas. Responden terkadang mengalami sulit tidur, hal tersebut responden atasi dengan mengkonsumsi obat tidur (aprazolam). Selain itu juga, responden juga mengalami penurunan gairah seksual, semenjak menggunakan metadon.

Mengenai kualitas hidup responden terkait kondisi psikologis, responden mengungkapkan semenjak menggunakan metadon kemampuan berpikir dan kepercayaan diri menurun, juga responden merasa dirinya tidak selincah dulu. Responden bertekad untuk lepas dari metadon dan meyakini pendekatan religi dan spiritual dapat membantu 
dirinya agar terlepas dari narkoba dan menjadi orang yang lebih baik. Responden tetap berpikir positif atas apa yang terjadi pada dirinya, dan mengambil hikmah terkait apa yang dialaminya. Semenjak menggunakan metadon responden lebih memperhatikan dirinya, baik dalam penampilan dan juga kebersihan.

Kualitas hidup terkait hubungan sosial responden tiga mengungkapkan bahwa mulai adanya perbaikan hubungan, pertengkaran dengan istri mulai berkurang, hubungan dengan anak juga membaik, namun istri responden belum percaya sepenuhnya terhadap responden dan masih mencoba memahami bahwa responden tidak boleh dijauhi. Penurunan gairah seksual juga responden rasakan, namun responden berupaya untuk memenuhi keinginan istrinya, bukan untuk kepuasan dirinya.

Terkait kualitas hidup mengenai lingkungan, sumber penghasilan menjadi suatu kendala, karena saat ini responden belum memiliki pekerjaan tetap. Responden saat ini menunggu warisan, agar dapat membeli rumah untuk keluarganya. Responden merasa perawatan metadon tidak jelas, sulit untuk menurunkan dosis, dan juga petugas medis sering lupa untuk menurunkan dosis. Mengenai rekreasi responden jarang melakukannya bersama keluarga, hal ini disebabkan karena istri responden yang sibuk bekerja meskipun dihari sabtu dan minggu sekalipun.

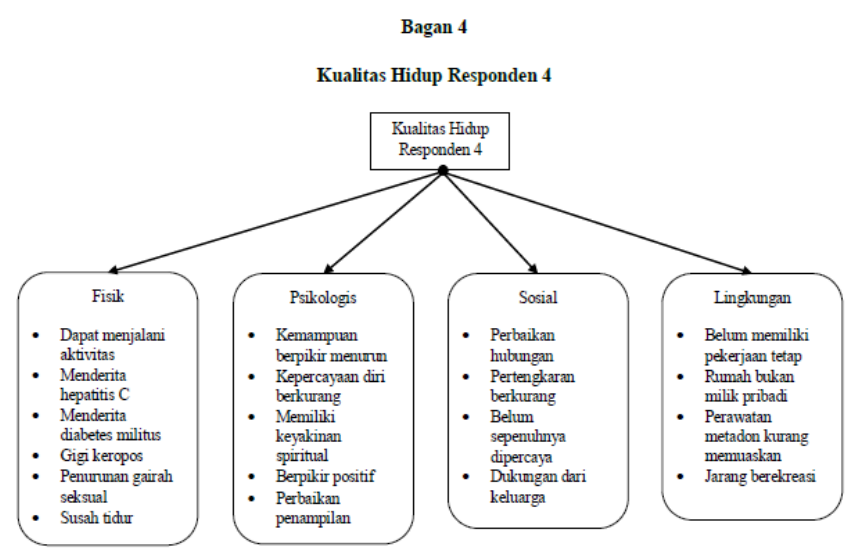

\section{Makna Kualitas Hidup Bagi Pengguna Metadon}

Responden satu memaknai kualitas hidup sebagai kehidupan yang sempurna yang tidak menggunakan narkoba. Responden menilai dirinya berada pada angka enam dari nilai kualitas hidup dengan rentang 1-10, karena melihat diri responden sebagai mantan pecandu yang memiliki kemungkinan untuk kambuh. Kini responden telah mengalami peningkatan, dengan hidup mandiri. Pada responden dua memaknai kualitas hidupnya dengan berusaha lebih dari sebelumnya, dengan berusaha berhenti dari pengobatan, mencoba bersosialisasi, dan bekerja lebih giat. Responden menilai kualitas hidup dirinya berada pada angka enam dengan rentang nilai 1-10 terkait kualitas hidup yang dirasakan, karena terdapat beberapa hal yang belum terpenuhi.
Responden berharap dapat lepas dari metadon dan mengembalikan kepercayaan dirinya.

Responden tiga memaknai kualitas hidup sebagai kondisi mampu dan nyaman dalam melakukan aktivitas, kecukupan finansial, hubungan spiritual dan di masyarakat terpenuhi. Responden menilai kualitas hidup dirinya berada pada angka empat dengan rentang nilai 1-10 terkait kualitas hidup yang dirasakan, karena terdapat beberapa faktor yang belum terpenuhi. Sementara itu responden empat memaknai kualitas hidup sebagai kehidupan dimana responden dapat beraktivitas normal. Kini responden sudah mulai ada perubahan, dengan kepercayaan diri yang diakui mulai meningkat, dan dapat bekerja dengan lebih baik meskipun masih serabutan. Responden menilai kualitas hidupnya saat ini berada pada angka tujuh dengan rentang nilai 1-10 terkait kualitas hidup yang dirasakan. Berat badan responden juga sudah mulai meningkat, dan penghasilan mulai ada, serta pengobatan alternatif terkait diabetes dirasa nyaman.

\section{PEMBAHASAN DAN KESIMPULAN}

\section{Dampak Penggunaan Metadon}

Dampak yang dapat terjadi pada pengguna metadon yaitu toleransi, ketergantungan, dan juga sakaw, bahkan sakaw yang dirasakan terasa lebih berat apabila dibandingkan dengan sakaw akibat opioid golongan lainnya, serta dapat terjadi kapan saja terutama pada dua minggu hingga enam bulan pertama (Prabowo, 2008). Berdasarkan hasil penelitian, responden mengungkapkan beberapa gejala yang timbul seperti tubuh menjadi berkeringat, tubuh terasa nyeri, nafsu makan menurun, perasaan gelisah, dan sulit mengendalikan emosi. Responden juga menyadari bahwa sakaw yang ditimbulkan oleh metadon dirasa lebih parah apabila dibandingkan dengan sakaw yang timbul akibat heroin. Ketika menggunakan heroin, responden mengungkapkan bahwa dengan memandikan diri tubuh kembali normal, namun berbeda ketika sakaw akibat metadon, meskipun telah mandi tetap saja tidak ada perubahan sehingga mendorong responden untuk segera menggunakan metadon.

Seluruh responden dalam penelitian ini sempat mengalami kesulitan buang air besar (sembelit) ketika menggunakan metadon dengan dosis yang tinggi, namun salah satu dari responden masih mengalami kesulitan dalam buang air besar. Hal ini disebabkan karena dosis penggunaan metadon pada responden masih terbilang tinggi yaitu berada pada dosis 100mg dan membuat responden sering kali menghabiskan waktu di kamar mandi selama berjam-jam. Hal ini didukung oleh hasil penelitian yang dilakukan oleh Bourgois (2000) yang mengungkapkan bahwa dampak yang paling utama dari penggunaan metadon yaitu mengalami konstipasi, otot terasa sakit, dan penurunan gairah seksual. 
Sesuai dengan yang dikemukakan oleh Bourgois (2000) terkait dampak dari metadon, responden dalam penelitian ini sebagian besar mengalami penurunan gairah seksual. Penurunan gairah seksual membuat intensitas dalam melakukan hubungan seksual menjadi menurun, hal ini cukup merugikan bagi salah satu responden, yang pada saat ini memiliki tujuan untuk segera memiliki anak. Hal lain yang juga dialami seluruh responden yaitu mengalami gangguan pada gigi, keempat responden merasakan efek metadon yang cukup besar yaitu gigi responden menjadi berlubang dan juga mengalami pengeroposan. Hal ini didukung oleh penelitian yang dilakukan oleh Zajdow (1999) yang mengungkapkan bahwa penggunaan metadon menyebabkan gigi menjadi keropos dan habis.

Penggunaan metadon juga menimbulkan dampak menurunnya kemampuan berpikir, hal ini dialami oleh salah satu responden yang mengakui kemampuan berpikirnya tidak lagi sama seperti dulu ketika masih menggunakan metadon. Responden mengaku lambat dalam berpikir dan tidak seperti dulu, dahulu responden mampu melihat peluang bisnis dengan cepat, sehingga memberikan keuntungan bagi dirinya. Responden menyadari bahwa dirinya mudah lupa, cepat merasa jenuh, dan juga mudah mengalami stres. Hasil ini didukung oleh penelitian yang diungkap oleh Darke (dalam Kugler, 2007) yang memberikan tes pada pasien terapi metadon berupa tes intelegensi, performa psikomotor, memproses informasi, perhatian, ingatan jangka pendek, ingatan jangka panjang, dan juga pemecahan masalah. Dari hasil tes ditemukan bahwa pasien yang sedang menjalani terapi secara signifikan mengalami gangguan pada semua area kecuali pada tes intelegensi, yang menjelaskan bahwa kemampuan responden terkait kecerdasan tidak mengalami gangguan atau penurunan.

Selama menjalani terapi metadon, permasalahan yang juga biasa terjadi adalah masalah kebebasan. Kebebasan merupakan suatu kondisi dimana indvidu dapat bertindak sesuai dengan keinginannya. Dalam hal ini pengguna metadon merasa tidak bebas dalam beraktivitas, hal ini terjadi pada seluruh responden penelitian. Terkadang responden mengalami kesulitan ketika harus bepergian keluar kota dalam kurun waktu yang lama, karena di satu sisi pemberian dosis bawa pulang diberikan secara terbatas kepada responden.

Dari sekian fakta yang memaparkan dampak yang cenderung negatif, penggunaan metadon juga memberikan dampak positif kepada penggunanya. Dampak positif yang pertama yaitu seluruh responden kini menjadi pribadi yang lebih memperhatikan diri dan penampilannya, hal ini terjadi setelah responden mulai menggunakan metadon dan berhenti menyalahgunakan narkoba. Allport (1921) menjelaskan bahwa melalui persepsi visual yang sangat singkat terjadilah suatu proses mental yang kompleks, dan dalam waktu singkat telah menghasilkan penilaian dan persepsi terhadap orang lain.
Sebagian besar orang hanya sepintas memperhatikan pakaian orang lain, tetapi ternyata bagaimana cara berpakaian seseorang menunjukkan informasi orang tersebut dan menjadi dasar dari kesan pertama. Perubahan penampilan yang ditunjukkan oleh responden dalam penelitian ini berupa kesadaran yang lebih akan kebersihan dan juga kerapian pada diri responden yang membuat responden merasa lebih percaya diri saat beraktivitas.

Sejauh ini penggunaan metadon dirasakan memberikan kenyamanan bagi responden meskipun terdapat efek samping selama penggunaannya, karena dengan metadon responden terhindar dari penggunaan jarum suntik. Hal ini sesuai dengan tujuan dari terapi metadon itu sendiri, yaitu terapi substitusi atau sebagai pengganti narkotika jenis heroin yang pada umumnya menggunakan jarum suntik, menjadi metadon dalam bentuk cair dan dikonsumsi dengan cara diminum atau oral (BNN, 2007). Penggunaan metadon juga membuat responden tidak merasakan kecemasan akan ditangkap polisi seperti ketika masih menggunakan narkoba dan tidak merasakan beban finansial sehingga membuat responden merasa nyaman dengan kondisinya saat ini yang diungkapkan oleh salah satu responden. Hal ini didukung oleh penelitian yang dilakukan oleh Xiao, dkk. (2010), terungkap bahwa terjadi peningkatan kesehatan mental, yang disebabkan oleh terapi metadon memungkinkan pasien untuk terbebas dari beban keuangan dan tidak perlu khawatir akan ditangkap karena metadon bersifat legal.

\section{Pembahasan Kualitas Hidup Responden}

\section{a. Pengertian Kualitas Hidup Menurut Responden}

Ruggeri, dkk. (2001) mengungkapkan bahwa penilaian kualitas hidup subjektif memiliki kemampuan prediktif yang lebih baik apabila dibandingkan dengan penilaian kualitas hidup objektif. Sehingga dalam hal ini pengukuran serta konsep dari kualitas hidup hendaknya terpusat pada persepsi subjektif individu terkait kualitas hidup yang dialaminya sendiri (Mendlowicz \& Stein, 2000). Kualitas hidup itu sendiri merupakan interaksi antara penghayatan subjektif bobot kepentingan dalam atau dari aspek-aspek kehidupan tertentu dengan beberapa faktor kondisi kehidupan yang dapat berpengaruh ataupun tidak, ditentukan dengan bagaimana individu mempersepsikan kondisi hidup yang dijalaninya (Nofitri, 2009).

Berdasarkan pengertian yang diungkapkan responden, dapat kesimpulan bahwa kualitas hidup merupakan suatu gambaran mengenai kehidupan yang dialami oleh seseorang yang dinilai dari berbagai faktor seperti pekerjaan, kesehatan, keteraturan pola hidup, ekonomi, pemenuhan kebutuhan, dan kenyamanan psikologis yang dirasakan oleh masing-masing individu. Kualitas hidup dikatakan baik apabila semua faktor dapat terpenuhi dengan baik dan secara seimbang dapat dinikmati oleh individu yang bersangkutan, 
serta hal yang paling utama yaitu terbebas dari narkoba dan dapat menyelesaikan terapi metadon, sehingga dapat terciptanya kondisi kehidupan yang lebih baik dari sebelumnya.

\section{b. Kondisi Serta Perubahan Fisik yang Terjadi}

Perubahan fisik merupakan perubahan fisiologis sebagai akibat dari usia dan genetik, gaya hidup dan faktor perilaku yang dimulai dari masa muda yang dapat memengaruhi kecenderungan, penentuan waktu, serta besarnya perubahan fisik yang terjadi Merill dan Verbrugge (dalam Papalia, Olds, \& Feldmen, 2009). Dengan alasan yang tidak berbeda kebiasaan dan juga gaya hidup yang dijalani pada waktu sebelumnya memengaruhi apa yang akan terjadi pada tahun-tahun berikutnya. Begitu pula dengan apa yang terjadi pada individu yang sedang menjalani terapi metadon, kondisi fisik serta perubahan fisik yang terjadi merupakan akibat dari gaya hidup yang dijalani pada masa sebelumya.

Bowling (2005) menyebutkan bahwa kriteria individu yang memiliki kualitas hidup positif ditandai dengan memiliki kesehatan fisik dan mental yang baik serta memiliki kemampuan fisik untuk melakukan hal-hal yang ingin dilakukan. Begitu pula dengan responden dalam penelitian ini, masing-masing responden masih dapat melakukan berbagai aktivitas yang ingin dilakukannya. Perubahan yang juga dialami oleh responden yaitu kini masing-masing responden dapat bekerja kembali. Masing-masing responden dapat menjalankan aktivitasnya seperti biasa, namun tidak dapat bekerja dalam kurun waktu yang cukup lama, hal ini disebabkan karena responden mudah mengalami kelelahan dalam bekerja. Hasil penelitian yang mendukung yaitu penelitian yang dilakukan oleh Maeyer, dkk. (2011) yang mengungkapkan bahwa metadon dapat membantu individu untuk dapat bekerja dan menjaga pekerjaannya, meskipun individu bekerja dibawah standar dan tidak menggunakan penuh kapasitas yang dimilikinya.

Menjalani pola hidup yang baik seperti istirahat dengan teratur merupakan hal penting yang perlu dilakukan dalam meningkatkan kondisi fisik yang lebih baik. Larasati (2009) menyebutkan bahwa individu yang kualitas hidupnya positif ditandai dengan menjaga kondisi tubuhnya dengan baik. Tidak demikian dengan responden dalam penelitian ini, sebagian responden sering mengalami sulit tidur, berdasarkan hasil penelitian pada salah satu responden sulit tidur yang dialaminya disebabkan karena dimalam hari responden harus menemani anaknya, dan ketika telah larut waktunya untuk tidur responden tidak merasa kantuk, sehingga hal tersebut membuat responden tidur hingga larut malam. Sementara itu pada responden lainnya, kesulitan tidur yang dialaminya karena responden mengerjakan pekerjaannya yang belum selesai, responden ini terbiasa meminum kopi di malam hari yang membuat responden tidak merasa kantuk. Selain itu responden ini terkadang mengalami sakit pinggang beserta keram, responden meyebutkan bahwa keram serta nyeri yang terjadi pada dirinya merupakan efek dari penggunaan AC dengan suhu yang cukup rendah.

Cella, dkk. (2003) menyebutkan bahwa kondisi kesehatan seseorang sangat memengaruhi kualitas hidupnya, maka dari itu menjaga kesehatan merupakan suatu hal yang perlu dilakukan guna meningkatkan kualitas hidup individu. Berdasarkan hasil penelitian terkait dengan penyakit yang dialami, sebagian besar responden mengaku menderita hepatitis $\mathrm{C}$, hepatitis $\mathrm{C}$ merupakan peradangan pada sel-sel hati yang disebabkan oleh virus hepatitis C (VHC). VHC menular melalui kontak dengan darah yang telah terinfeksi virus hepatitis $\mathrm{C}$. Dalam hal ini ketiga responden terjangkit virus hepatitis $\mathrm{C}$ ketika masih menggunakan narkoba suntik. Menderita hepatitis $\mathrm{C}$ membuat responden tidak bebas dalam beraktivitas dan kesulitan untuk berolahraga guna menjaga kesehatannya, hal ini dirasakan oleh salah satu responden yang tidak diijinkan berolahraga secara berlebihan, namun di satu sisi responden ingin menurunkan berat badannya.

Selain menderita hepatitis $\mathrm{C}$, terdapat juga responden lainnya yang juga menderita diabetes militus, Taylor (dalam Taylor, dkk., 2009) mengungkapkan bahwa penyakit kronis seperti diabetes dapat memengaruhi semua kehidupan individu. Pekerjaan bisa terancam, hilang, atau mungkin seseorang akan mengalami cacat. Hal tersebut juga terjadi pada responden empat, setelah terdiagnosa diabetes militus responden mulai tidak aktif dalam bekerja yang mengurangi pendapatan keluarganya.

\section{c. Kesejahteraan dan kenyamanan psikologis}

Untuk menghindari sugesti terhadap narkoba yang muncul, responden dituntut untuk dapat menyusun koping strategi, koping merupakan usaha pemecahan masalah dan usaha pengaturan emosi untuk mereduksi tekanan (Taylor, 2009). Dalam hal ini strategi koping yang dilakukan responden yaitu dengan memunculkan kembali pengalaman yang dialaminya ketika masih menggunakan narkoba. Lain halnya dengan yang dialami oleh salah satu responden, strategi koping yang dilakukan responden yaitu dengan meminta bantuan istri untuk menemani responden ketika mengambil metadon. Hal tersebut dirasa efektif karena hingga saat ini responden tidak lagi mengalami kekambuhan penggunaan narkoba.

Bowling (2005) juga menjelaskan terkait kriteria individu yang memiliki kualitas hidup positif yaitu dengan memiliki pandangan psikologis yang positif dan mampu menjaga kestabilan emosinya. Berdasarkan hasil penelitian sebagian responden mulai menunjukkan perubahan dalam mengontrol emosi, responden dapat mengambil keputusan dengan bijaksana, mencoba memahami keadaan orang lain, dan berusaha mengurangi pertengkaran yang sebelumnya 
sering terjadi. Lain halnya dengan yang dialami oleh salah satu responden yang masih mengalami kesulitan dalam mengontrol emosinya, hal ini terjadi ketika responden merasa efek dari metadon telah hilang dalam tubuhnya dan sedang mengalami masalah.

Secara keseluruhan responden dalam penelitian perlahan mulai dapat menerima kondisi dan keadaan dirinya saat ini, pada dasarnya penerimaan diri merupakan sikap positif yang ditunjukkan terhadap diri serta dapat menerima dengan tenang dan puas dengan keadaan diri baik dalam hal kelebihan maupun kekurangan yang ada dalam dirinya (Chaplin, 1999). Penerimaan diri juga ditandai dengan adanya semangat juang dalam menjalani kehidupan sehari-hari. Pada individu yang sedang menjalani terapi metadon, semangat juang dapat ditunjukkan dengan motivasi yang kuat untuk menjalani terapi metadon dan berusaha untuk benar-benar sembuh dan tidak ketergantungan lagi. Dalam penelitian ini sebagian responden memiliki motivasi yang kuat untuk menurunkan dosis penggunaan metadon yang telah dijalaninya selama ini, hal ini ditunjukkan dengan menetapkan target kapan responden akan berhenti menggunakan metadon. Sementara itu terdapat sebagian responden lainnya yang merasa jenuh setelah menyadari penggunaan metadon yang dijalaninya telah berlangsung dalam kurun waktu yang cukup lama.

Penggunaan metadon juga menyebabkan kemampuan berpikir responden menurun, hal ini dialami oleh responden keempat yang mengakui kemampuan berpikirnya telah berubah setelah menggunakan metadon. Responden mengaku lambat dalam berpikir dan tidak seperti dulu, dahulu responden mampu melihat peluang bisnis dengan cepat, sehingga memberikan keuntungan bagi dirinya. Responden menyadari dirinya mudah lupa, cepat merasa jenuh, dan juga mudah mengalami stres. Hasil ini didukung oleh penelitian yang diungkap oleh Darke (dalam Kugler, 2007) yang memberikan tes pada pasien terapi berupa tes intelegensi, performa psikomotor, memproses informasi, perhatian, ingatan jangka pendek, ingatan jangka panjang, dan juga pemecahan masalah. Dari hasil tes ditemukan bahwa pasien yang sedang menjalani terapi secara signifikan mengalami gangguan pada semua area, kecuali pada tes intelegensi.

Berdasarkan hasil penelitian, ditemukan bahwa terjadi ekspresi spiritual pada individu yang sedang menjalani terapi metadon, ekspresi spiritual yang terjadi berupa rasa syukur, pasrah, dan meningkatkan ibadah. Ekspresi ini dialami oleh salah satu responden, berdasarkan hasil wawancara dipahami bahwa pengalaman hidup sebagai mantan pecandu narkoba membuat responden sadar akan hikmah dibalik pengalamannya. Potter dan Perry (2005) mengungkapkan bahwa individu akan memperoleh manfaat yang besar ketika individu menggunakan kepercayaannya sebagai kekuatan yang dapat memberikan dukungan terhadap kesehatannya. Hal ini sesuai dengan apa yang diungkapkan oleh sebagian responden, dimana sebagian responden mengatakan bahwa dengan mendekatkan diri kepada Tuhan dengan melakukan kegiatan keagamaan membuat responden menjadi lebih tenang, dan dalam hal ini responden merasakan sugesti untuk menggunakan narkoba menjadi lenyap begitu saja.

\section{d. Hubungan sosial}

Hubungan responden dengan orang-orang disekitarnya kini mulai membaik, responden mulai diterima oleh orang-orang disekitarnya. Sudah mulai ada penerimaan dari orang sekitar, namun sebagian responden belum dapat sepenuhnya terlibat dalam aktivitas di masyarakat. Shin dan Johnson (dalam Bowling, 2005) menjelaskan bahwa kualitas hidup terdiri dari keinginan serta harapan, kepemilikan sumber daya guna pemuasan kebutuhan hidup, dan partisipasi dalam aktivitas yang memungkinkan pengembangan pribadi serta aktualisasi diri. Keterlibatan dalam aktivitas sosial merupakan salah satu kriteria yang mengarahkan individu dalam membangun kualitas hidup positif.

Salah satu faktor yang memengaruhi keterlibatan responden di masyarakat yaitu budaya Hindu Bali yang menuntut individu untuk terlibat aktif di masyarakat dalam kegiatan gotong royong yang berkaitan dengan ritual keagamaan ataupun masalah sosial kemasyarakatan yang disebut dengan istilah ngayah. Apabila anggota dari masyarakat tidak ngayah, maka akan dikenakan sanksi berupa denda, dan lebih parah lagi dapat kasepekang atau dikucilkan (Titib, 2005). Terdapat responden yang mengalami hal tersebut, meskipun responden dituntut untuk terlibat aktif di masyarakat, namun responden merasa belum mampu karena takut akan pandangan negatif masyarakat tentang dirinya yang pernah menggunakan narkoba. Sementara itu pada salah satu responden lainnya, meskipun penerimaan telah kembali namun responden menyadari bahwa waktu yang diberikan untuk keluarga dan masyarakat masih kurang, hal ini disebabkan oleh keinginan responden untuk fokus dengan pekerjaan yang dijalaninya, dan apabila telah mapan barulah saat itu responden akan membagi waktunya dengan adil. Terdapat juga responden yang telah mampu menyesuaikan diri dengan masyarakat, dalam hal ini individu telah mampu terlibat aktif dalam kegiatan bermasyarakat seperti terlibat dalam pertemuan maupun bergotong royong.

Seluruh responden kini mulai diterima oleh orangorang disekitarnya, namun kepercayaan orang lain terhadap masing-masing responden belum sepenuhnya percaya. Hal ini serupa dengan penelitian yang dilakukan oleh Chou (2013) dan hasil yang diperoleh yaitu tidak terjadi perubahan yang signifikan pada aspek sosial dalam 6 bulan pertama, hal ini dikarenakan dalam membangun kembali hubungan sosial dibutuhkan waktu yang cukup untuk mendapatkan kembali kepercayaan dari anggota maupun masyarakat. 
Tidak jarang stigma negatif masih dirasakan responden, hal ini terjadi pada salah satu responden. Salah satu tetangga responden masih ada yang menganggap responden menggunakan narkoba. Sesuai dengan yang diungkapkan oleh Maeyer, dkk. (2011) yang mengemukakan bahwa ketika membicarakan mengenai pengaruh metadon terhadap hubungan sosial, hal yang sering dirasakan oleh individu yaitu stigma negatif dalam kehidupan sosial mereka. Seperti contoh ketika individu ingin membeli metadon, sering timbul perasaan bahwa keluarga dan masyarakat tidak mengetahui apa metadon sebenarnya, bagi mereka metadon sama halnya dengan narkoba yang menimbulkan ketidakpercayaan secara mendalam.

Taylor (2009) mengungkapkan bahwa dukungan sosial diyakini dapat menguatkan individu dalam menghadapi efek dari stres dan memungkinkan terjadinya peningkatan fisik. Dalam penelitian ini, dukungan yang diterima oleh mantan pecandu narkoba yang sedang menjalani terapi metadon berupa dukungan emosi, materi, dan juga informasi yang diterima dari keluarga dan masyarakat sekitar. Dukungan yang diberikan dilakukan dengan cara yang berbeda-beda antara kerabat satu dengan kerabat lainnya, namun terdapat pula kesamaan dalam memberikan dukungan yang berupa dukungan emosional, dukungan finansial, maupun dukungan informasi.

\section{Dukungan emosional}

Robert dan Gilbert (2002) mengungkapkan bahwa dukungan emosional yaitu adanya seseorang yang dapat memberikan dorongan, mendengarkan, serta dapat memahami dan menyenangkan perasaan seseorang. Dalam penelitian terlihat adanya dukungan emosional yang diberikan keluarga kepada responden dalam menjalani terapi metadon. Salah satu responden mendapatkan dukungan dari orangtuanya, dan responden lainnya merasakan dukungan yang sangat berarti yang bersumber dari istri. Berdasarkan hasil penelitian, dukungan emosional yang diterima oleh orangtua selain memberikan kasih sayang juga membantu responden dalam bekerja, dimana hal ini dialami oleh salah satu responden. Ibu responden membantu pekerjaan responden yang bekerja di LSM dengan membantu membagikan media kepada klien anaknya apabila anaknya sedang tidak dirumah atau sedang beristirahat. Sementara itu terdapat seorang responden yang mendapat dukungan dari istri yang selalu menemani responden ketika akan mengambil metadon.

\section{Dukungan material}

Dukungan material merupakan dukungan yang dibutuhkan oleh masing-masing responden untuk memenuhi kebutuhan sehari-hari dan juga akses pelayanan kesehatan (Nursalam, 2007). Dari keempat responden, terdapat seorang responden yang saat ini belum memiliki pekerjaan tetap. Untuk memenuhi kebutuhan selama ini responden meminta kepada istri apabila sedang tidak memiliki uang, begitu pula dengan apa yang dialami oleh responden lainnya, meskipun telah memiliki pekerjaan tetap apabila responden kekurangan uang maka responden akan meminta uang kepada orangtuanya, hal ini dapat meringankan beban subjek yang secara tidak langsung dapat mengurangi timbulnya stres negatif pada individu.

3. Dukungan informasi

Dukungan informasi merupakan dukungan dimana seseorang memberikan pengajaran terhadap orang lain, pemberian saran, informasi, atau membantu dalam membantu mengambil keputusan (Nursalam, 2007). Berdasarkan hasil penelitian ditemukan bahwa pemberian dukungan informasi diberikan oleh keluarga dengan mengingatkan, serta memberitahukan jadwal dan waktu untuk meminum metadon setiap harinya. Khususnya pada hari-hari tertentu seperti hari raya, dimana klinik metadon akan tutup. Hal ini bertujuan agar tidak timbul lagi gejala sakaw yang pernah dirasakan masingmasing responden. Pemberian dukungan informasi yang diterima responden tidak hanya berasal dari keluarga namun juga datang dari orang yang ada di sekitarnya, dan juga pihak rumah sakit. Informasi diperoleh ketika responden mengikuti konseling dan pertemuan kelompok, dalam pertemuan tersebut responden akan mendapatkan informasi terkait kesehatan dan lain sebagainya.

\section{e. Kebebasan dan kenyamanan terhadap lingkungan}

Kebebasan merupakan komponen terpenting dalam peningkatan kualitas hidup individu yang sedang menjalani terapi metadon. Seluruh responden telah mengalami ketergantungan terhadap metadon selama bertahun-tahun, dan hal ini menghasilkan kualitas hidup yang rendah bagi responden. Selama menjalani terapi ini responden dituntut untuk mengkonsumsi metadon setiap hari dengan dosis tertentu. Menggunakan metadon membantu individu untuk dapat beraktivitas normal dan bekerja kembali, hal ini didukung oleh pernyataan yang disampaikan oleh Ruefli dan Rogers (2004) yang menyebutkan bahwa salah satu cara yang dapat membantu individu yang sedang menjalani terapi metadon adalah membantunya dalam mencari pekerjaan. Memiliki pekerjaan dan memiliki penghasilan sendiri dapat meningkatkan harga diri individu dan merasa tidak terlalu terbebani masalah finansial. Status pekerjaan merupakan salah satu hal yang turut memengaruhi kualitas hidup, dalam penelitian ini sebagian besar responden telah memiliki pekerjaan tetap sehingga responden tidak terlalu mempermasalahkan finansial. Lain halnya dengan apa yang dialami oleh seorang responden yang saat ini belum memiliki pekerjaan tetap, hal ini juga berdampak pada hubungan responden dengan istrinya yang sering mempermasalahkan kekurangan finansial. 
Buchanan (dalam Preedy \& Watson, 2010) mengungkapkan definisi dari kualitas hidup secara fungsional berkaitan dengan persepsi individu terhadap kinerja baik secara fisik, keuangan, maupun pekerjaan. Sebagian responden dalam penelitian ini bekerja pada LSM yang bergerak di bidang kesehatan serta penanggulangan bahaya narkoba, hal tersebut memberikan keuntungan bagi responden berupa informasi dan juga pengetahuan terhadap penyakit yang membuat responden memahami apa yang harus dilakukan dan apa yang harus dihindari untuk meningkatkan kesehatannya. Salah satu responden juga mengungkapkan bahwa bekerja di sebuah lembaga penanggulangan bahaya narkoba membuat dirinya memahami apa yang pernah terjadi pada dirinya dulu, sehingga hal ini menjadi pelajaran penting bagi responden untuk memahami tujuan dari hidup dan dapat meningkatkan kualitas hidup yang positif.

Terkait dengan perawatan kesehatan dalam menjalani terapi metadon, dalam penelitian ini tergambar bahwa responden merasa kurang puas dengan pelayanan serta perawatan yang diberikan di klinik PTRM RSUP Sanglah. Parasuraman (dalam Tjiptono, 1997) mengungkapkan bahwa aspek mutu dan kualitas pelayanan adalah keandalan, ketanggapan, jaminan, kepedulian, dan pemberian bantuan langsung. Sikap yang ditunjukkan dalam penelitian ini berdasarkan pengakuan responden yang mengatakan bahwa pelayanan yang diberikan kurang maksimal. Berdasarkan pengakuan salah satu responden, penurunan kualitas layanan terjadi karena responden merasa kurangnya konseling yang diberikan kepada pasien dalam menjalani terapi. Selain itu pengecekan-pengecekan kesehatan yang dahulu sering dilakukan, kini jarang dilakukan.

Dalam menurunkan dosis pun dirasa sangat sulit, hal ini berdasarkan penuturan responden lainnya yang menyebutkan bahwa perawat tidak tanggap dalam memenuhi permintaan pasien, perawat sering mengaku lupa ketika menurunkan dosis metadon pada responden, dimana sebelumnya responden meminta bantuan kepada perawat agar mengatur penurunan dosis responden. Asmadi (2008) menyebutkan bahwa sebagai seorang tenaga ahli profesional hendaknya dapat memberikan kualitas layanan yang memaksimal serta dapat menunjukkan kepedulian terhadap apa yang dibutuhkan individu yang menjalani terapi. Tidak demikian dengan sebagian responden, apa yang diungkapkan responden menunjukkan ketidakpuasan terhadap pelayanan yang diterimanya selama menjalani terapi metadon.

Mengenai keselamatan fisik serta kenyamanan yang dirasakan responden, secara keseluruhan responden memiliki tempat tinggal yang ditempatinya bersama dengan keluarga masing-masing. Bowling (2005) menyebutkan bahwa memiliki tempat tinggal dalam lingkungan yang aman disertai fasilitas yang baik, dapat memenuhi kebutuhan secara mandiri, dan memiliki cukup uang merupakan kriteria-kriteria yang menentukan bahwa individu memiliki kualitas hidup yang baik. Terkait dengan hal ini sebagian responden dalam penelitian mengakui bahwa mereka merasa kurang nyaman dengan lingkungan tempat tinggalnya saat ini. Seperti yang dialami oleh salah satu responden yang tidak jarang mencium aroma kotoran babi, karena memiliki tetangga yang memelihara babi, dan terdapat juga responden yang tinggal dengan kondisi rumah rawan terkena banjir apabila sedang musim hujan.

\section{f. Makna kualitas hidup}

Browne, dkk. (1997) memaparkan bahwa setiap individu memiliki definisi yang berbeda terhadap kualitas hidup yang baik atau buruk, hal ini didasarkan pada reaksi dari masing-masing individu terkait persepsi mereka terhadap kualitas hidup. Begitu pula dalam memaknai kualitas hidup yang dirasakan, masing-masing individu memiliki penilaian yang berbeda dalam memaknai kualitas hidupnya yang didasarkan atas kepentingan individu terhadap aspek kehidupan. Secara garis besar, individu yang sedang menjalani terapi metadon memaknai kualitas hidupnya sebagai suatu proses menuju perubahan kehidupan yang menuntut individu untuk menjadi individu yang memiliki kualitas hidup lebih baik lagi dalam berbagai aspek kehidupan baik dalam kondisi kesehatan, sosial, status ekonomi, maupun spiritual. Sebagian besar responden merasa dirinya belum mencapai kualitas hidup yang diharapkannya, sehingga hal ini mengarahkan individu untuk melakukan upaya efektif agar dapat meningkatkan kualitas hidupnya.

g. Faktor yang memengaruhi kualitas hidup mantan pecandu narkoba yang sedang menjalani terapi metadon

Fadda dan Jiron (1999) mengatakan bahwa kualitas hidup antar individu akan bervariasi pada individu yang tinggal pada suatu wilayah dengan wilayah lainnya, dan hal ini tergantung dari sistem nilai, konteks budaya, maupun aturan yang berlaku pada wilayah tersebut. Avis, Crawford, dan Manuel (2005) menyebutkan bahwa beberapa faktor demografi juga memengaruhi kualitas hidup seseorang seperti usia, jenis kelamin, hubungan interpersonal, pekerjaan, pendidikan, penghasilan, dan status pernikahan. Berdasarkan hasil penelitian terdapat beberapa faktor yang memengaruhi kualitas hidup individu yang sedang menjalani terapi metadon seperti pekerjaan, hubungan interpersonal, status pernikahan, penghasilan, dan budaya.

Konteks budaya merupakan salah satu faktor yang memengaruhi kualitas hidup individu yang sedang menjalani terapi metadon. Sebagian besar responden hidup dalam budaya adat yang menuntut anggotanya untuk berpartisipasi aktif di dalam kegiatan adat seperti ngayah (gotong royong), sangkeb (rapat), dan lain sebagainya. Berdasarkan hasil penelitian ditemukan bahwa terdapat responden yang 
mengalami kesulitan untuk memenuhi hal tersebut, karena menyadari latar belakang dirinya sebagai pecandu narkoba, sehingga responden merasa takut untuk berpartisipasi aktif. Terdapat juga responden yang lebih mengutamakan pekerjaannya, karena latar belakang sebagai mantan pecandu narkoba, menuntut responden untuk memperbaiki diri terlebih dahulu dalam hal pekerjaan agar menjadi lebih baik lagi.

Moons, dkk. (2004) mengungkapkan bahwa terdapat perbedaan kualitas hidup pada individu yang berstatus sebagai pelajar, individu yang memiliki pekerjaan, individu yang tidak bekerja atau sedang mencari pekerjaan, dan individu yang tidak mampu bekerja atau mengalami disability tertentu. Terlihat salah satu responden belum memiliki pekerjaan tetap, hal ini membuat kebutuhan sehari-hari responden masih bergantung kepada istrinya dan berdampak pada hubungan sosial responden dengan istrinya.

Atwater (1983) mengungkapkan bahwa status pekerjaan dapat sangat berpengaruh terhadap kepuasan dalam pekerjaan, dan berdampak pada kesejahteraan individu. Terdapat responden yang merasa mudah lelah dalam bekerja, hal ini responden rasakan sebagai akibat penggunaan metadon dalam waktu yang cukup lama. Salah satu responden juga merasa jenuh dengan pekerjaannya karena mengalami kesulitan dalam bekerja yaitu menjangkau klien yang ditugaskan kepadanya, selain itu responden merasa pekerjaannya berisiko karena memungkinkan responden mengalami hal yang tidak terduga seperti menginjak jarum suntik yang pernah dialaminya.

Faktor demografi seperti penghasilan juga turut memberikan pengaruh terhadap kualitas hidup individu yang sedang menjalani terapi metadon. Atwater (1983) menyebutkan bahwa penghasilan berkaitan dengan status pekerjaan individu, yaitu individu yang memiliki status pekerjaan baik cenderung memiliki penghasilan yang lebih baik pula, sehingga berdampak pula pada kualitas hidup seseorang. Berdasarkan hasil penelitian sebagian responden telah memiliki pekerjaan tetap, sehingga tiap bulannya responden mendapatkan penghasilan dari pekerjaan yang dijalaninya. Terdapat responden yang mengakui penghasilan yang diperolehnya belumlah mencukupi, selain karena kebutuhan yang semakin meningkat juga dipengaruhi oleh diri responden yang merasa kurang mampu dalam mengatur keuangan. Terdapat juga responden yang belum memiliki pekerjaan tetap, sehingga penghasilan yang diperoleh tidak menentu dan responden bergantung kepada istrinya.

Hubungan interpersonal berdasarkan hasil penelitian juga ditemukan bahwa memengaruhi kualitas hidup individu yang sedang menjalani terapi metadon. Robbins (1999) mengungkapkan bahwa hubungan interpersonal merupakan interaksi yang terjadi antara individu dengan individu lainnya dalam situasi tertentu ataupun dalam kelompok sebagai motivasi untuk mencapai kepuasan psikologis, sosial, dan ekonomi yang berdampak pada peningkatan kualitas hidup. Terkait dengan hal ini, responden mendapatkan dukungan dari keluarga untuk menjalani terapi metadon, seperti yang dialami oleh seorang responden yang selalu ditemani istri ketika mengambil metadon, hal ini membantu responden agar tidak tergoda lagi apabila ada yang menawarkan narkoba karena istri yang selalu mengawasi responden. Hubungan interpersonal juga berkaitan dengan hubungan responden dengan perawat dalam menjalani terapi metadon. Berdasarkan hasil penelitian, responden mangakui pentingnya peranan perawat dalam menurunkan dosis penggunaan metadon, dalam hal ini terdapat responden yang kurang puas dengan pelayanan yang diterimanya.

Berdasarkan keseluruhan pembahasan, dapat disimpulan bahwa kualitas hidup individu yang sedang menjalani terapi metadon dapat dipengaruhi oleh beberapa hal diantaranya dampak dari penggunaan metadon, faktor budaya, status pekerjaan, penghasilan, dan hubungan dengan orang sekitar. Kualitas hidup yang ditampilkan tidak hanya sebatas hasil dari pengalaman selama menggunakan metadon, namun juga sebagai hasil dari pengalaman-pengalaman terdahulu termasuk pengalaman sebagai mantan pecandu narkoba. Kualitas hidup ditunjukkan dari empat aspek kehidupan seperti fisik, psikologis, sosial, dan juga lingkungan, yang memiliki keterkaitan antara satu aspek dengan aspek lainnya.

Pada aspek fisik individu merasa lebih prima selama menggunakan metadon dibandingkan ketika masih menggunakan narkoba. Hal ini ditunjukkan dengan dapat kembali bekerja dan melakukan aktivitas sehari-hari, meskipun mudah mengalami kelelahan, sulit beristirahat, dan terdapat kerusakan organ tubuh. Pada aspek psikologis individu kini merasa diri lebih berguna, mulai mampu mengambil keputusan, mengalami perbaikan dalam penampilan, meskipun timbul rasa tidak nyaman apabila belum menggunakan metadon, emosi menjadi tidak stabil, dan pada situasi tertentu adanya sugesti untuk menggunakan narkoba. Pada aspek hubungan sosial terjadinya perbaikan hubungan dengan orang sekitar, merasa bertanggungjawab, meskipun belum sepenuhnya dapat berfungsi secara normal di masyarakat, dan masih adanya stigma terhadap individu pengguna metadon. Pada aspek kesejahteraan lingkungan individu pengguna metadon mengalami peningkatan status ekonomi, pengetahuan yang meningkat, dan berhenti dari penyalahgunaan heroin. Di sisi lain individu merasa kebebasannya berkurang, dan adanya kebutuhan untuk terus menggunakan metadon.

Terkait pemaparan mengenai kualitas hidup, responden yang menjalani terapi ini sebaiknya meningkatkan usaha-usaha yang bermanfaat pada peningkatan kualitas hidup. Pengawasan serta perhatian merupakan komponen penting yang membantu responden dalam menjalani terapi metadon dengan baik, sehingga keluarga hendaknya dapat 
meberikan bantuan yang benar-benar dibutuhkan oleh responden selama menjalani terapi metadon. Bagi lembaga yang menyediakan pelayanan terapi metadon, sebaiknya meningkatkan kembali kualitas dari pelayanan, sehingga memberikan kepuasan bagi responden dalam menjalani terapi. Bagi penelitian selanjutnya dapat dilakukan dengan lebih fokus pada salah satu aspek kehidupan, sehingga hasil yang diperoleh lebih mendalam, dan dapat menggunakan responden dengan kriteria yang bervariasi, seperti usia, jenis kelamin, jumlah relapse yang dialami, sehingga ditemukan perbedaanperbedaan antar individu atau kelompok.

\section{DAFTAR PUSTAKA}

Abidin, Z. (2002). Analisis Eksistensial Untuk Psikologi dan Psikiatri. Bandung: Refika Aditama.

Adisti, Susi. (2007). Belenggu Hitam Pergaulan: Hancurnya Generasi Akibat Narkoba. Jakarta: Restu Agung.

Agung. (2010). Pasien Korban Penyalahguna Narkoba Di Tempat Terapi dan Rehabilitasi di 13 Provinsi. Diakses: November, 2013 dari website: bnn.go.id/portalbaru/portal/file/hasil_penelitian/pasien.korb an.penyalahguna.narkoba.di.tempat.terapi.dan.rehabilitasi.d i.13.provinsi.di.pdf

Allport, G.W. (1937). Personality: A Psychology Interpretation. New York: Holt

Asmadi, N. 2008. Konsep Dasar Keperawatan. Jakarta: Penerbit Buku Kedokteran EGC.

Atwater, E. (1983). Psychology of Adjustment: Personal Growth in a Changing World. 2nd. Ed. New Jersey: Prentice-Hall.

Avis, N., Crawford, S., \& Manuel, J. (2005). Quality of Life Among Younger Women With Breast Cancer. Journal of Clinical Oncology, 23, 15, 1-9.

Baharom, N., Hassan, M. R., Ali, M. L., \& Shah, A. (2012). Improvement of Quality of Life Following 6 Months of Methadone Maintenance Therapy in Malaysia. Substance Abuse Treatment, Prevention, and Policy Journal, 7, 32, 16.

Bastaman, H. D. (2007). Logoterapi. Psikologi untuk Menemukan Makna Hidup dan Meraih Hidup Bermakna. Jakarta: PT. Raja Grafindo Persada.

BNN (Badan Nasional Narkotika). (2007). Survei Nasional Penyalahgunaan Dan Peredaran Gelap Narkoba Tahun 2003, Puslitbang \& Info Lakhar BNN. Diakses: November, 2013 dari website: http://www.bnn.go.id

Bourgois, P. (2000). Disciplining Addictions: The Bio-Politics of Methadone and Heroin in The United States. Culture, Medicine, and Psychiatry Journals, 24, 165-195

Bowling, A. 2005. Measuring Health: A Review of Quality of Life Measurement Scales. New York: Bell \& Bain Ltd.

Calman, K. C. (1984). Quality of Life in Cancer Patients - An Hypothesis. Journal of Medical Ethics, 10, 124-127.

Cella, D., Zagari, M., Vandoros, C., Gagnon, D., Hurtz, H., \& Nortier, J. (2003). Epoetin Alfa Treatment Results in Clinically Significant Improvements in Quality of Life in Anemic Cancer Patients When Referenced to the General Population. Journal of Clinical Oncology, 21, 2, 366-373.
Chaplin. J.P. 1999. Kamus Lengkap Psikologi, (Kartini Kartono, pen). Cetakan kelima: Raja Grafindo Persada.

Chou, Y., Shih, S.., Tsai, W., Li, C., Xu, K., \& Lee, T. S. (2013). Improvement of quality of life in methadone treatment patients in northern Taiwan: a follow-up study. Journal BMC Psychiatry, 13, 190-197.

Creswell, J. W. (1998). Qualitative Inquiry and Research Design: Choosing Among Five Tradition. London: Sage Publication.

Depkes RI. (2007). Modul dan Kurikulum Program Terapi Rumatan Metadon. Jakarta: Departemen Kesehatan RI.

Fadda, G., \& Jiron, P. (1999). Quality of Life and Gender: A Methodology for Urban Research. Environment and Urbanization Journal, 11, 261-271.

Herdiansyah, H. (2010). Metode Penelitian Kualitatif Untuk IlmuIlmu Sosial. Jakarta: Salemba Humanika

Iswanti, D. I., Suhartini, \& Supriyadi. (2007). Koping Keluarga Terhadap Anggota Keluarga Yang mengalami Ketergantungan Narkoba Di Kota Semarang. Jurnal Undip, 1, 1. 1-35

Kugler, L. M. (2007). Methadone Maintenance Therapy And Its Effects On Executive Functioning. US: ProQuest Information and Learning Company.

Larasati. 2009. Kualitas Hidup Pada Wanita yang Sudah Memasuki Masa Menopouse. Skripsi Universitas Gunadarma.

Lasmawan, G. I. S. (2013). Gambaran Resiliensi Mantan Pecandu Narkoba (Studi Kasus Pada Pasien PTRM Sanglah yang Juga Bekerja di LSM. Studi Kasus (Tidak dipublikasikan). Program Studi Psikologi Fakultas Kedokteran Universitas Udayana, Denpasar.

Maeyer, J. D., Vanderplasschen, W., Camfield, L., Vanheule, S., Sabbe, B., \& Broekaert, E. (2011). A Good Quality of Life Under The Influence of Methadone: A Qualitative Study Among Opiate-Dependent Individuals. International Journal of Nursing Studies, 48, 1244-1257.

Manurung, N. K. (2009). Kebijakan Kriminal (Criminal Policy) Terhadap Anak Pemakai Narkoba di Kota Medan. Tesis. Sekolah Pascasarjana, Universitas Sumatera Utara, Medan.

Mendlowicz, M. V., \& Stein, M. B., (2000). Quality of Life in Individuals With Anxiety Disorders. Journal Psychiatry, 157, 669-682.

Moons, P., Marquet, K., Budts, W., \& De Geest, S. (2004). Validity, reliability and responsiveness of the Schedule for the Evaluation of Individual Quality of Life - Direct Weighting (SEIQoL-DW) in congenital heart disease. Health and Quality of Life Outcomes Research, 2, 27-34.

Nofitri, N. F. M. (2009). Quality of Life Among Adult Citizen of Five Area In Jakarta. Skripsi. Fakultas Psikologi Universitas Indonesia, Depok.

Nursalam, M. (2007). Asuhan Keperawatan Pada Pasien HIV/AIDS. Jakarta: Salemba Medika.

Okvianus, P. P. (2010). Perilaku Pengguna Napza Suntik Di Dalam Mengikuti Program Terapi Rumatan Metadon Di RSUP H. Adam Malik Medan Tahun 2010. Skripsi. Fakultas Kesehatan Masyarakat. Universitas Sumatera Utara

Papalia, D. E., Olds, S. W., \& Feldman, R. D. (2009). Human development (ed.11). New York: McGraw-Hill. 
Parasuraman, A., Zeithaml, V., \& Berry, L. (1985). A Conceptual Model of Service Quality and Its Implications for Future Research. The Journal of Marketing, 49, 4, 41-50.

Partodihardjo, S. (2010). Kenali Narkoba dan Musuhi Penyalahgunaannya. Jakarta: Erlangga.

Potter, \& Perry. (2005). Buku Ajar Fundamental Keperawatan: Konsep, Proses, dan Praktik. Jakarta: EGC.

Prabowo, B. R. (2008). Yang Perlu Anda Ketahui Dari Metadon. Diakses: November, 2013 dari website: http://dokterbagus.com

Preedy, V., \& Watson, R. Handbook of Disease Burdens and Quality of Life Measures. USA: Springer

Preston, A. (2006). Buku Saku Metadon. Jakarta: RSKO

Puspita, W. (2008). Dinamika Program Rumatan Metadon Di RSKO Jakarta. Skripsi. Fakultas Kesehatan Masyarakat Universitas Indonesia, Jakarta.

Robbins, S. (1990). Prinsip-Prinsip Perilaku Organisasi. Jakarta: Erlangga.

Roberts, A., \& Gillbert, J. (2002). Buku Pintar Pekerja Sosial-Jilid 2 (J. Damanik \& C. Pattisiana, pen). Jakarta: Gunung Mulia.

Ruefli, T., \& Rogers, S. J. (2004). How do Drug Users Define Their Progress in Harm Reduction Programs? Qualitative Research to Develop Usergenerated Outcomes. Harm Reduction Journal, doi:10.1186/1477-7517, 1-8.

Sarafino, E. P. (2006). Health Psychology. USA: Copyright Clearance Center. inc.

Setyawan, I. (2012). Sistem Penghukuman Bagi Pecandu Narkotika Pada Undang - Undang No 35 Tahun 2009 Tentang Narkotika. Skripsi. Fakultas Hukum Univeristas Sumatera Utara, Medan.

Simarmata, C. (2013). Sikap dan Pengetahuan Remaja Tentang Tindakan Penyalahgunaan Narkoba : (Studi Deskriptif Pada Siswa/Siswi SMP SWASTA Jambi Di Kelurahan Bantan Kecamatan Medan Tembung). Skripsi. Departemen Sosiologi Universitas Sumatera Utara, Medan.

Stewart, A. L., \& Ware, J. E. (1992). The Medical Outcome Study (MOS): Measuring Functioning and Wellbeing. USA: The Rand Corporation.

Subali, B. (2010). Metode Penelitian Pendidikan Biologi. Diakses: November, 2013

dari website:http://staff.uny.ac.id/system/files/pendidikan/Bamb ang\%20Subali,\%20Dr/metodologi\%20penelitian\%20pendi dikan\%20biologi.pdf

Taylor, S. E., Peplau, L. A., Sears, D. O., (2009) . Psikologi Sosial (ed. ke-12). Jakarta: Kencana Prenada Media Group.

Titib, M. (2005). Dialog Ajeg Bali: Perspektif Pengalaman Agama Hindu. Michigan: Paramita

Ventegodt, S., Merrick, J., \& Andersen, N. J. (2003). Quality of Life Teori I. IQOL Theory: An Integrative Theory of the Global Quality of Life Concept. The Scientific World Journal, 3, 1030-1040.

Wasis, \& Irianto, S. Y. (2008). Ilmu Pengetahuan Alam. Jakarta: Pusat Perbukuan, Departemen Pendidikan Nasional.

WHO. (1997). Programme on Mental Health: Measuring Quality of Life. Division of Mental Health and Prevention of Substance Abuse. p. 1-13.
Xiao, L., Wu, Z., Luo, W., \& Wei, X. (2010). Quality of Life of Outpatients in Methadone Maintenance Treatment Clinics. Journal Acquir Immune Defic Syndr. 1: S116, 1-11

Zajdow, G. (1999). Learning Live Without It: Women, Biography, and Methadone. Hecate Journal, 25, 2, 63-79. 